\section{Det hellige som kilde til helse}

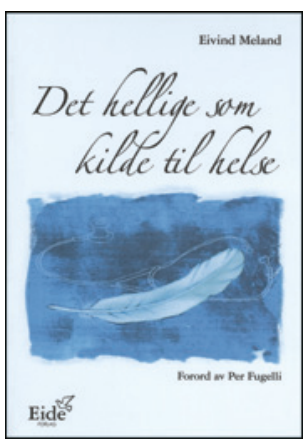

Eivind Meland

Det hellige som kilde til helse

138 s, ill. Stavanger: Eide Forlag, 2012

Pris NOK 295

ISBN 978-82-514-0775-5

Eivind Meland har skrevet om det hellige som kilde til helse.

Han fremholder hvordan religiøse begreper er blitt fremmede i vår verdslige samtid, og vil gjenopprette respekten for det som er hellig i livet. De troende har ikke monopol på hellighetsbegrepet. Dette er felles- eller allmennreligiøst og bør gjøres relevant for alle, også for dem som ikke bekjenner seg til en konfesjon. Han gjeninnfører begreper som omvendelse, nåde, hellighet og kjærlighet og forankrer disse $\mathrm{i}$ en livsfilosofi hvor tro på naturen og takknemlighet er det sentrale. Vi tilhører og bæres oppe av noe større enn oss selv, av livet og naturen.

Meland er kritisk til den moderne medisinen som gjennom sitt søkelys på teknikk og prøvetaking glemmer de relasjonelle aspektene. Forfatteren påpeker hvordan den sekulære vitenskapen har tapt på ensidig å fokusere på vitenskapens verdensbilde og overse de åndelige aspektene ved tilværelsen. Når vitenskap og teknologi er det eneste vi «tror på», har vi fått en mager religionserstatning.

Trenger vi med større frimodighet å vise for pasienter og kolleger at kjærlighet og tillit er allmennreligiøse og helsebringende elementer i våre liv? Har den sekulære korrektheten brakt oss alle til taushet i en tid som mer enn før trenger budskap om nåde, selvempati, nestekjærlighet og ærefrykt for naturen?

Forfatteren vil ikke gjøre seg til talsperson for å misbruke konsultasjonen til å fremme trosbekjennelser og konfesjoner. Men det ligger et farlig selvbedrag i den motsatte ytterligheten: en fjern og instrumentell tilnærming til pasienten. Vi skal ikke fremme trosmessige særinteresser eller opptre som bedrevitende, men det er mer ødeleggende ikke å drøfte spørsmål av verdimessig og allmennreligiøs karakter.

Meland etterlyser en «humanistisk medisin», et tredje standpunkt i motsetning til en tradisjonell kristen og sekulær filosofi. Han mener at det hellige representerer en allmennreligiøs mulighet til å bedre helsen, til å bedre relasjonen mellom oss og til å ta et større ansvar for natur og miljø.

Det er fortjenstfullt at forfatteren våger å rette oppmerksomheten mot den åndelige dimensjon i tilværelsen, et område som medisinen og psykologien har vært lite opptatt av. Han har laget en praktisk sekulær livsfilosofi, hvor han på en interessant måte kombinerer ulike vitenskaper. Etter min mening problematiserer han imidlertid for lite hva man mister når tradisjonelle kristne begreper tas ut av sin sammenheng.

Jeg anbefaler boken. Den vil være interessant lesning både for medisinere, teologer og andre interesserte.

\section{Atle Roness}

Bergen

\section{Liv uten livets rett}

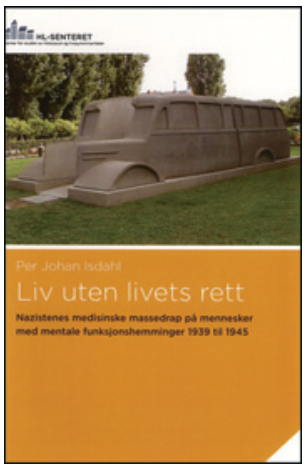

Per Johan Isdahl
Liv uten livets rett

Nazistenes medisinske massedrap på mennesker med mentale funksjonshemminger 1939 til 1945. 29 s, ill. Oslo: HL-senteret, 2012. Pris NOK 70 ISBN 978-82-92988-16-9

Knapt 65 år etter avslutningen av Legeprosessen i Nürnberg erkjente den tyske legeforeningen gjennom sin Nürnberger Erklärung av 23. mai 2012 de tyske legenes ansvar for de medisinske uhyrlighetene i $1933-45(1,2)$.

Vi har alle hørt om jødeforfølgelsene, utryddelsesleirene og Josef Mengeles (1911-79) eksperimenter i Auschwitz. I etterkrigsårene har den tyske legeforeningen vært avvisende til at disse årene skulle bli gjenstand for forskning, fordi det kunne ødelegge legenes rykte. Det den tyske legeforeningen nå i klartekst sier, er at legenes deltakelse ikke var noe som bare gjaldt de skrekkelige, eller at det kun avspeilet et politisk press. De mer enn 360000 tvangssteriliserte, drapene på mer enn 200000 mentalt syke og invalide, de fryktelige medisinske forsøkene og utvelgelsen av de som skulle til konsentrasjonsleirene, var ikke et resultat av noen få fanatikeres virksomhet, men krevde deltakelse fra store deler av det medisinske samfunnet. Ledende tyske leger og forskere deltok med glød i å rense fedrelandet. Mange av dem hadde vært ledende fagfolk før 1933, de var ledende i 1933-45 og fortsatte som ledende fagpersoner etter 1945.

Den tyske legeforeningen erkjenner i sin erklæring hvor galt det kan gå hvis ikke en grunnleggende etikk ligger til grunn for vår virksomhet.

Psykolog Per Johan Isdahl har i Holocaustsenterets skriftserie utgitt et hefte om en av de største medisinske ugjerningene i det 20. århundre - ja, kanskje overhodet. Det er et lite hefte, men stoffet er overveldende. Utryddelsen av handikappede barn og voksne hadde et dobbelt formål: Det skulle rense rasen, og det skulle fjerne de som først og fremst ble sett på som en økonomisk byrde. Drapene og drapsmetodene ble forløperne og «treningsfeltet» for de massedrapene som, særlig på jøder, skjedde i tyske konsentrasjonsleire.

Det er et opplysende, rystende og tankevekkende hefte. På enkelte punkter er fremstillingen upresis. Jon Alfred Mjøen (1860-1939) og hans pseudovitenskapelige laboratorium på Vinderen fikk aldri noen stor betydning for norsk praksis, men det fikk derimot genetikeren, professor Otto Lous Mohr (1886-1967), og hans motstand mot eugenisk tankegang. Det er riktig at Lov nr. 2 til vern av folkeætten (1943-45) åpnet for tvangssterilisering av personer som led av alvorlige, arvelige sykdommer eller defekttilstander. Den ga juridisk dekning for en praksis vi så lenger syd og øst i Europa, men den medførte her ikke de samme uhyrlighetene.

Heftet anbefales varmt til alle som er interessert $i$ den annen verdenskrig, og til kolleger med interesse for medisinsk etikk.

\section{Per E. Børdahl}

Kvinneklinikken

Haukeland universitetssykehus

Im Gedenken an die Opfer der Medizin im Nationalsozialismus. www.ippnw.de/commonFiles/pdfs/Soziale_Verantwortung/ Appell_Deutscher_Aerztetag_2012.pdf (23.11.2012).

2. Kolb $S$, Weindling $P$, Roelcke $V$ et al. Apologising for Nazi medicine: a constructive starting point. Lancet 2012; 380: 722-3. www.thelancet.com/journals/ lancet/article/PIIS0140-6736(12)61396-8/fulltext (23.11.2012). 